\title{
Analisis Pengaruh Suhu dan Kelembaban Ruang terhadap Kadar Air Benih Padi di Gudang Penyimpanan PT. Sang Hyang Seri
}

\section{(Analysis of the Effect of Temperature and Humidity of Room on Rice Seed Water Content in PT. Sang Hyang Seri (Persero))}

\author{
Muhammad Fachruri $^{1 *}$ ), Junaedi Muhidong ${ }^{2)}$, Muhammad Tahir Sapsal ${ }^{3)}$ \\ 1) Program Studi Keteknikan Pertanian Universitas Hasanuddin \\ 2) Program Studi Keteknikan Pertanian Universitas Hasanuddin \\ 3) Program Studi Keteknikan Pertanian Universitas Hasanuddin \\ ${ }^{*}$ Email korespondensi: fachrurimuhammad@gmail.com
}

\begin{abstract}
ABSTRAK
Peningkatan produksi pangan membutuhkan ketersediaan benih yang bermutu. Salah satu masalah dalam penyediaan benih bermutu yaitu viabilitas benih yang menurun dalam masa penyimpanan, penelitian mengenai hal tersebut masih jarang dilakukan, Selama proses penyimpanan suhu dan kadar air benih merupakan faktor penting yang mempengaruhi masa simpan benih. Penelitian ini dilakukan untuk mengetahui pengaruh suhu dan kelembaban terhadap kadar air pada benih selama penyimpanan pada gudang PT Sang Hyang Seri (Persero). Benih padi merupakan benih orthodox yaitu benih yang dapat disimpan dalam waktu yang relatif lama dengan kadar air dapat diturunkan sampai dibawah 10\%, Dalam pengumpulan data khususnya data temperatur gudang penyimpanan digunakan area sampling, area sampling merupakan cara pengambilan sampel dengan menetapkan area secara equally spaced (bagian yang sama). Data sampel yang diperoleh terdiri dari sejumlah nilai-nilai pengamatan yang rata-rata hitungnya (arithmatic mean) dapat langsung dicari dari data yang bersangkutan. Hasil penelitian menunjukkan bahwa korelasi suhu interstisial bulk benih $28-29^{\circ} \mathrm{C}$ dan suhu ruang penyimpanan tidak menunjukkan pengaruh terhadap kadar air benih padi $13-14 \%$ selama 15 hari penyimpanan, tingkat kelembaban ruang $45-50 \%$ merupakan faktor yang berpengaruh terhadap penurunan kadar air benih sebesar $1 \%$ selama penyimpanan.
\end{abstract}

Kata kunci : Benih, Penyimpanan, Suhu, Kelembaban, Kadar Air

\section{PENDAHULUAN}

Penyimpanan benih yaitu upaya pelestarian benih yang mempunyai daya hidup, mulai dari pengumpulan hingga berakhir di lapangan sampai dengan saat akan digunakan kembali sebagai bahan tanam. Tujuan utama penyimpanan benih adalah agar benih dapat ditanam pada tahun yang sama dilain musim, atau untuk tujuan pembudidayaan benih dari suatu jenis tanaman.

Tujuan utama benih yang disimpan ialah untuk mengawetkan cadangan bahan tanam dari satu musim ke musim selanjutnya, benih yang tersimpan dengan baik diharapkan viabilitasnya tetap tinggi pada akhir masa penyimpanan. Masalah dalam penyimpanan benih adalah penurunan viabilitas benih sejalan dengan 
waktu. Semakin lama benih disimpan, viabilitas benih akan semakin menurun.

Suhu ruang penyimpanan dan kadar air benih merupakan faktor penting yang mempengaruhi masa simpan benih maka dari itu penelitian ini dilakukan untuk mengetahui apakah suhu, kelembaban ruang memiliki pengaruh terhadap kadar air pada benih selama penyimpanan dalam gudang PT Sang Hyang Seri (Persero).

\section{METODOLOGI PENELITIAN}

\section{Waktu dan Tempat}

Penelitian ini dilakukan pada November 2017 sampai dengan April 2018 bertempat di PT. Sang Hyang Seri, Kabupaten Maros, Provinsi Sulawesi Selatan dan di Fakultas Pertanian Universitas Hasanuddin, Makassar.

\section{Alat dan Bahan}

Dalam Penelitian ini alat alat yang digunakan yaitu: Kamera, Termokopel, Komputer, Higrometer, Moisture Meter, Stopwatch, Alat tulis serta software Microsoft office excel.

Adapun bahan yang digunakan pada penelitian ini yaitu benih padi varietas Mekongga.

\section{Prosedur Penelitian Persiapan}

Kegiatan persiapan penelitian meliputi penyiapan alat-alat yang akan digunakan, pemilihan titik pengambilan data lalu memasang alat-alat yang akan digunakan.

\section{Pelaksanaan}

Pelaksanaan penelitian dilakukan dengan tahapan sebagai berikut:

1. Menetukan lokasi dan titik pengamatan.

2. Memasang alat-alat yang akan digunakan.

3. Melakukan pengambilan data di lapangan dan laboratorium.
4. Mengolah data menggunakan beberapa software.

Data yang dibutuhkan

1. Suhu

a. Melakukan pengukuran suhu pada setiap titik pengamatan.

b. Melakukan pengolahan data menggunakan software office excel.

2. RH ruangan

a. Memasang Environment Meter disekitar objek pengukuran.

b. Mengukur dan mencatat perubahan RH ruangan perhari.

3. Kadar Air

a. Mengambil sampel seberat 20 gram pada titik tiap titik, kemudian megukur kadar airnya memakai Grain Moisture meter.

b. 2. Mencatat data pada setiap titik pengamatan.

\section{Metode Pengumpulan Data}

Dalam pengumpulan data khususnya data temperatur gudang penyimpanan digunakan area sampling, area sampling merupakan cara pengambilan sampel dengan menetapkan area secara equally spaced (bagian yang sama). Pengambilan data dilakukan sebagai berikut :

1. Mengukur RH dan suhu ruang penyimpanan benih menggunakan higrometer multifunction environment meter.

2. Menentukan sebuah stapel tumpukan (Bulk) benih pada penyimpanan benih dalam gudang, ukuran stapel $2 \times 3,5 \mathrm{~m}$, membagi 3 bagian yaitu bagian pinggir dengan kedalaman $20-30 \mathrm{~cm}$, bagian tengah $50-60 \mathrm{~cm}$ dan bagian belakang yaitu bagian yang letaknya $15-20 \mathrm{~cm}$ dengan dinding penyimpanan, tampak pada gambar berikut. 


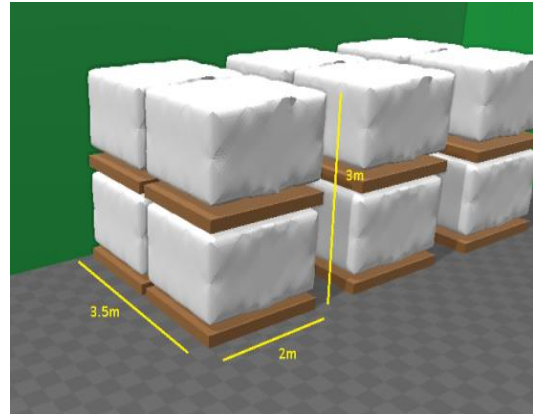

Gambar 6. Stapel Tumpukan Benih (Bulk)

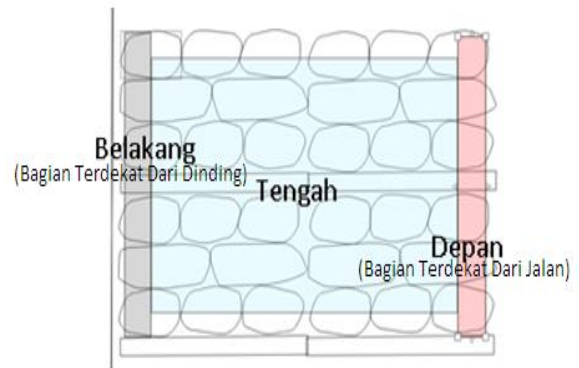

Gambar 7. Tampak Samping Pembagian Area Titik Pengukuran Suhu

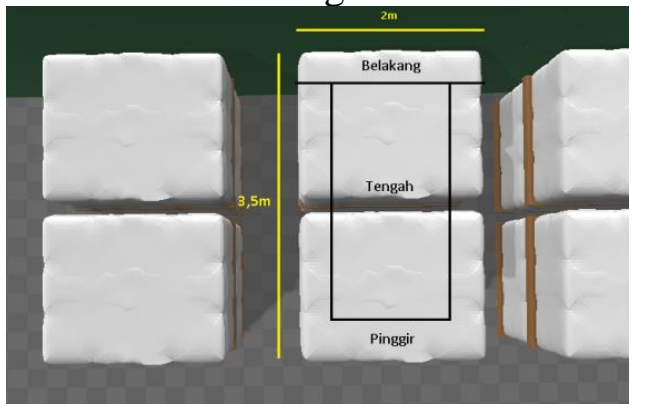

Gambar 8. Tampak Atas Pembagian Area

Titik Pengukuran Suhu

3. Penentuan titik pengukuran suhu dilakukan pada setiap bagian dengan menetapkan 2 titik pengukuran, data yang diambil merupakan jenis data yang mewakili area tertentu yang sudah ada batasnya.

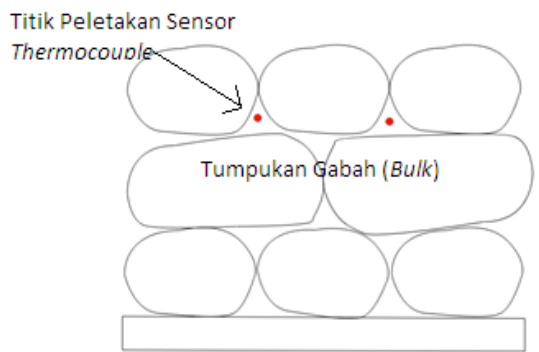

Gambar 9. Titik peletakan sensor thermocouple pada permukaan bulk benih
4. Mengukur temperatur pada titik yang telah ditentukan menggunakan thermocouple bersamaan dengan itu aktifkan stopwatch dan tunggu sampai indikator suhu benar benar konstan dan catat hasil pembacaan thermocouple lalu pindah ketitik berikutnya.

5. Mengambil sampel benih sekitar 20 gram pada setiap bagian dan ukur kadar airnya menggunakan Grain Moisture Meter.

6. Pengambilan data dilakukan selama 15 hari berturut turut pada 3 waktu yaitu pagi, siang, dan sore hari.

Data sampel yang diperoleh terdiri dari sejumlah nilai-nilai pengamatan yang rata-rata hitungnya (arithmatic mean) dapat langsung dicari dari data yang bersangkutan, rata-rata hitung dinyatakan dengan rumus :

$$
\bar{x}=\frac{1}{n} \sum_{i=1}^{n} x_{1}
$$

Keterangan :

$\bar{x}=$ rata-rata hitung

$x_{i}=$ nilai sampel

$\mathrm{n}=$ jumlah sampel

Selanjutnya dilakukan pembandingan variabel yang bertujuan untuk melihat variabel mana yang saling berpengaruh satu sama lain menggunakan rumus korelasi sebagai berikut :

Keterangan :

$$
\operatorname{Correl}(X, Y)=\frac{\sum(x-\bar{x})(y-\bar{y})}{\sqrt{\sum(x-\bar{x})(y-\bar{y})^{2}}}
$$

$\bar{x}=$ rata-rata variabel 1

$\bar{y}=$ rata-rata variabel 2

\section{HASIL DAN PEMBAHASAN}

\section{Gambaran Umum Penyimpanan Benih PT Sang Hyang Seri (Persero)}

Areal atau Lokasi merupakan salah satu faktor yang menentukan kelangsungan usaha dapat berjalan dengan baik. Letak Gudang Penyimpanan PT. Sang Hyang 
Seri satgas Maros berada di Jalan Kariango No. 67, Km 3 Mandai, Kabupaten Maros, Sulawesi Selatan. Batas-batas areal gudang penyimpanan adalah :

1. Sebelah Timur berbatasan lantai jemur

2. Sebelah Selatan berbatasan dengan aneka jenis tanaman pertanian.

3. Sebelah Barat berbatasan dengan lantai jemur

4. Sebelah Utara berbatasan denagan bangunan perkantoran

5. Penyimpanan dikelilingi oleh jalanan aspal

Bagian Penyimpanan :

a. Gudang : $(30 \times 15 \mathrm{~m})$

b. Ruang Mesin : (10 x 5m)

c. Kapasitas : (2000ton)

Standar mutu produk yang ditetapkan oleh perusahaan untuk setiap benih kantong adalah sebagai berikut :

1. Kadar air yang terkandung dalam Benih Lulus (BL) sebesar $12 \%$

2. Benih murni dalam Benih Lulus (BL) $99,7 \%$

3. Kotoran benih yang terdapat dalam Benih Lulus (BL) 0,2\%

4. lain yang terkandung dalam Benih Lulus (BL) $0,1 \%$

5. Daya tumbuh atau daya berkecambah Benih Lulus (BL) 85\%

6. Bebas dari hama dan penyakit.

Suhu

Suhu yang diperoleh selama 15 hari pengamatan pada tiga waktu berbeda yaitu pagi siang dan sore hari ditampilkan pada gambar berikut.

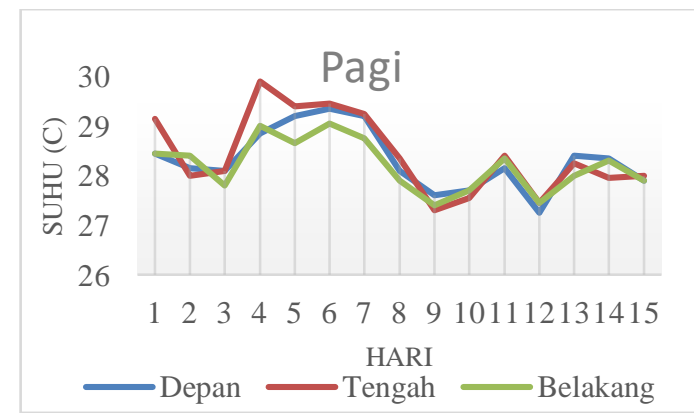

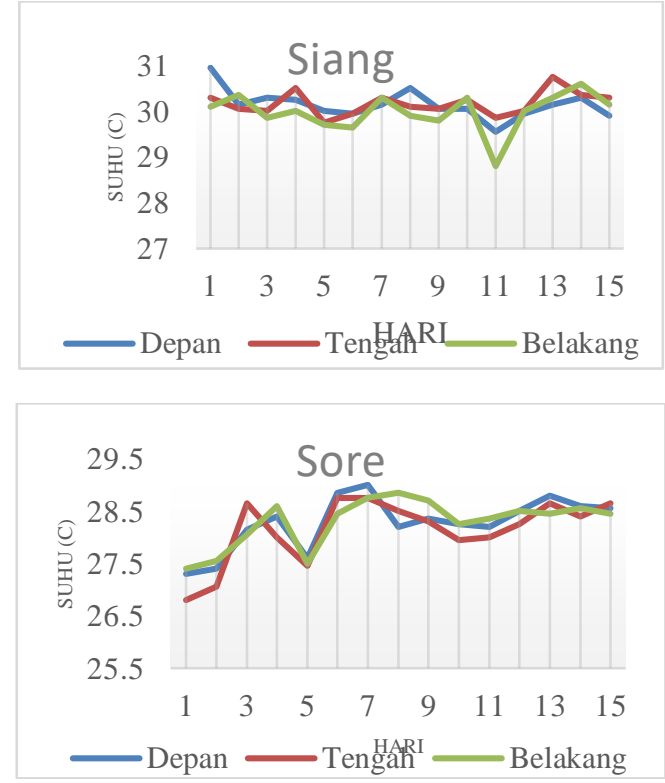

Gambar 9. Suhu Interstisial Bulk Benih

Pada gambar di atas menunjukkan perbandingan suhu interstisial bulk benih pada tiga waktu berbeda yaitu pagi siang dan sore, pada pagi hari kisaran suhu rata rata antara $27-29^{\circ} \mathrm{C}$, pada siang hari rataan suhu meningkat menjadi $28-30^{\circ} \mathrm{C}$, kemudian menurun kembali di sore hari menjadi $26-28^{\circ} \mathrm{C}$, kondisi tersebut sesuai dengan kondisi lingkungan yang pada siang hari cenderung lebih panas karena adanya perbedaan sudut kemiringan sinar matahari yang datang, pada pagi dan sore hari, sinar matahari datang miring dari timur (pagi) dan barat (sore) sehingga luasan yang terkena sinar matahari akan lebih luas daripada sinar yang datang tegak lurus dari atas.

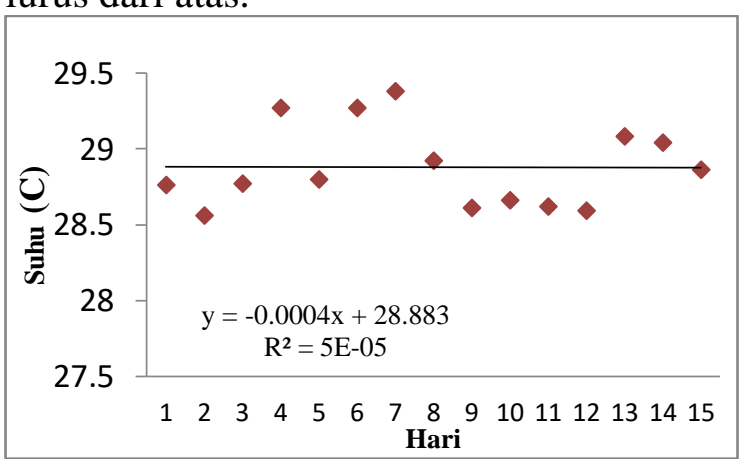

Gambar 10. Rerata Suhu Interstisial hari 1 $-15$ 


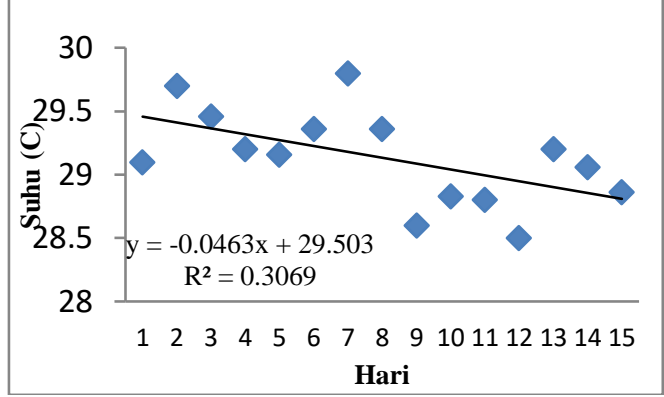

Gambar 11. Trend Suhu Ruang Hari 1 - 15

Gambar 10 Merupakan rata-rata dari grafik suhu pada pagi, siang dan sore hari, pada grafik tersebut dapat dilihat bahwa temperatur rata rata cenderung konstan pada suhu $28-29^{\circ} \mathrm{C}$, sedangkan gambar 11 menunjukkan trend suhu ruang penyimpanan benih selama 15 hari yang cenderung turun pada kisaran $28-29^{\circ} \mathrm{C}$ disebabkan adanya pergerakan udara dalam jumlah kecil, Suhu interstisial disekitar bulk cenderung lebih panas menyebabkan terjadinya keseragaman suhu benih yang disimpan karena partikelnya berukuran kecil, Berdasarkan prinsip lump capacity, hambatan internal perpindahan panas dapat diabaikan yang menyebabkan keseragaman suhu pada bahan (Singh dan Heldman, 2001). Sehingga suhu interstisial bulk cenderung lebih seimbang dibandingkan suhu lingkungan.

Menurut Imdad dan Nawangsih (1995), kisaran suhu ruang penyimpanan yang baik untuk kadar air bahan yang aman adalah $25-27^{\circ} \mathrm{C}$ ini menunjukkan bahwa ruang penyimpanan selama penelitian memiliki suhu yang cukup tinggi, untuk digunakan sebagai penyimpanan, benih yang disimpan pada kondisi suhu rendah dan kadar air rendah akan berdaya kecambah tinggi. Apabila kondisi suhu terlalu tinggi mikroorganisme perusak dan serangga akan mudah berkembang.

\section{RH Ruangan}

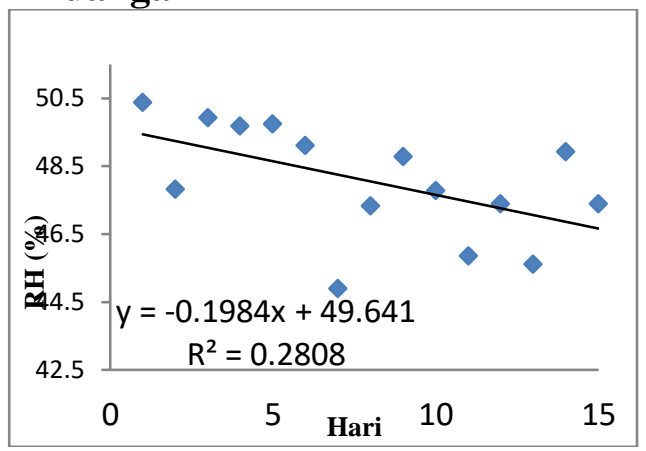

Gambar 12. Rerata Tingkat Kelembaban

Ruang Hari 1 - 15

Gambar 12 menunjukkan tingkat kelembaban ruang penyimpanan benih selama 15 hari, pada grafik tersebut terlihat bahwa rataan kelembaban berkisar antara $45-50 \%$, Menurut Imdad dan Nawangsih (1995), kisaran kelembaban yang baik untuk kadar air benih yang aman adalah 50 $-60 \%$, ini berarti bahwa ruang penyimpanan benih memiliki tingkat kelembaban yang cukup rendah. Kelembaban yang tinggi dapat mempercepat pertumbuhan dan berkembangnya mikroorganisme perusak, kelembaban yang tinggi juga akan menyebabkan terjadinya penyerapan uap air dari udara yang akan mengakibatkan bahan lembab yang berpengaruh terhadap kenaikan kadar air. Fluktuasi suhu dan kelembaban lingkungan penyimpanan secara alamiah juga akan menyebabkan terjadinya perpindahan uap air sehingga mendorong terjadinya kerusakan fisik pada benih yang disimpan.

\section{Kadar Air Benih}

Suhu penyimpanan dan kadar air benih merupakan faktor penting yang mempengaruhi masa simpan benih, berikut merupakan grafik perbandingan kadar air benih pada tiga waktu berbeda yaitu pagi siang dan sore selama 15 hari. 


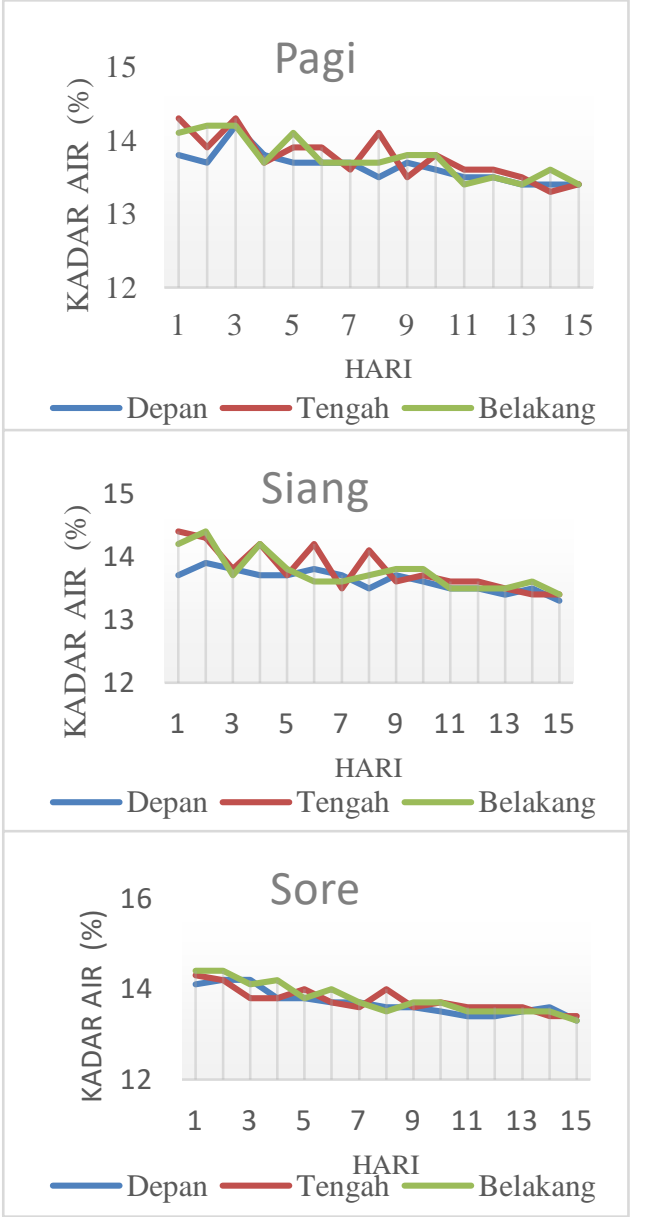

Gambar 13. Kadar Air Benih

Gambar di atas menunjukkan antara perbandingan kadar air pada pagi siang dan sore hari selama 15 hari penyimpanan rataan kadar air benih berkisar antara 13 14\%, Menurut Shaban (2013), benih padi merupakan benih orthodox yaitu benih yang dapat disimpan dalam waktu yang relatif lama dengan kadar air dapat diturunkan sampai dibawah $10 \%$, kadar optimum dalam penyimpanan bagi sebagian besar benih adalah antara $6-8 \%$ (Rajjou, 2012), ini berarti bahwa kadar air benih yang disimpan masih belum optimum kadar air yang terlalu tinggi dapat menyebabkan naiknya aktifitas pernafasan dan perkembangan cendawan yang dapat merusak kemurnian benih apabila terlalu rendah akan merusak embrio.

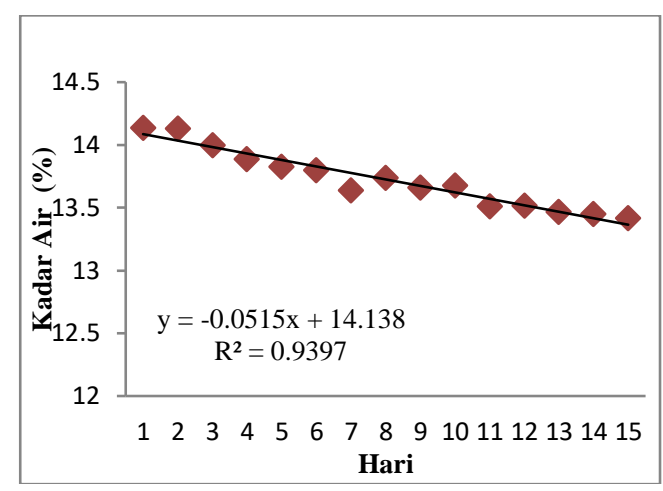

Gambar 14. Rata-rata Kadar Air Hari 1-15

Gambar di atas setelah dirata-ratakan, gambar tersebut menunjukkan penurunan kadar air sebesar 1\% selama 15 hari pengamatan pada penyimpanan benih.

Hubungan Suhu di sekitar Bulk Benih, Suhu Ruang Simpan dan Tingkat Kelembaban Terhadap Kadar Air.

Tabel 1. Data Rerata Suhu, Kadar Air, RH dan Suhu Ruang.

\begin{tabular}{lllll}
\hline Hari & $\begin{array}{l}\text { Rerata } \\
\text { Suhu } \\
\left({ }^{\circ} \mathrm{C}\right)\end{array}$ & $\begin{array}{l}\text { Rerata } \\
\text { Suhu } \\
\text { Ruang } \\
\left({ }^{\circ} \mathrm{C}\right)\end{array}$ & $\begin{array}{l}\text { RH } \\
(\%)\end{array}$ & $\begin{array}{l}\text { Rerata } \\
\text { Kadar } \\
\text { Air }(\%)\end{array}$ \\
\hline 1 & 28.76 & 29.1 & 50.4 & 14.14 \\
2 & 28.56 & 29.7 & 47.83 & 14.13 \\
3 & 28.77 & 29.46 & 49.93 & 14 \\
4 & 29.27 & 29.2 & 49.7 & 13.89 \\
5 & 28.8 & 29.16 & 49.76 & 13.83 \\
6 & 29.27 & 29.36 & 49.13 & 13.8 \\
7 & 29.38 & 29.8 & 44.9 & 13.64 \\
8 & 28.92 & 29.36 & 47.33 & 13.74 \\
9 & 28.61 & 28.6 & 48.8 & 13.66 \\
10 & 28.66 & 28.83 & 47.8 & 13.68 \\
11 & 28.62 & 28.8 & 45.86 & 13.51 \\
12 & 28.59 & 28.5 & 47.4 & 13.52 \\
13 & 29.08 & 29.2 & 45.63 & 13.47 \\
14 & 29.04 & 29.06 & 48.93 & 13.45 \\
15 & 28.86 & 28.86 & 47.4 & 13.42 \\
\hline
\end{tabular}

Diperoleh korelasi rataan suhu bulk dengan kadar air sebesar -0.1, korelasi RH dan kadar air sebesar 0.6 dan nilai korelasi antara suhu ruang dan kadar air sebesar 0.4 , untuk menentukan keeratan pengaruh digunakan kriteria Guilford (1996).

Tabel 2. Kriteria Guilford (1996).

\begin{tabular}{ll} 
Koefisien Korelasi & Kategori \\
$=0.20$ & Sangat Rendah \\
$>0.40$ & Rendah \\
$>0.50-0.60$ & Cukup Bararti \\
$>0.70-0.90$ & Kuat \\
\hline
\end{tabular}


Hasil tersebut menunjukkan bahwa tingkat kelembaban memiliki pengaruh cukup kuat terhadap kadar air benih selama penyimpanan, kelembaban yang rendah menyebabkan terjadinya perpindahan uap air dari bahan secara alamiah yang akan mengakibatkan bahan menjadi kering hal ini kemudian berpengaruh terhadap penurunan kadar air. Benih bersifat higroskopis yaitu selalu berusaha mencapai kondisi equilibrium dengan lingkungannya (Hartono, 2010). Ketika kelembaban udara pada tempat penyimpanan benih cenderung rendah, dimana kadar airnya lebih rendah daripada kadar air benih, maka kadar air benih juga akan mengalami penurunan.

\section{KESIMPULAN}

Berdasarkan hasil dan pembahasan, Kesimpulan sebagai berikut:

1. Suhu interstisial bulk benih dan suhu ruang penyimpanan tidak menunjukkan pengaruh terhadap kadar air benih selama 15 hari penyimpanan.

2. Tingkat kelembaban merupakan faktor yang berpengaruh pada penurunan kadar air benih selama penyimpanan.

\section{DAFTAR PUSTAKA}

Guilford, J.P. 1996. Fundamental Statistic in Psychology and Education. 3rd Ed. New York: McGraw-Hill Book Company, Inc.

Hartono, 2010. SPSS 16.0 Analisis Data Statistik dan Penelitian Edisi-2. Yogjakarta : Pustaka Pelajar

Imdad, H. P. dan A. A. Nawangsih. 1995. Sayuran Jepang. Penebar Swadaya. Jakarta, hlm 76-78

Rajjou, L. I. 2012. Seed Germination and Vigor. Plant Biol. 63(33):507-533.
Shaban, M. 2013. Aging in orthodox seeds is a problem. Adv Biol Biom Res, 1(11): 1296-1301

Singh, Paul R, Heldman, Dennis R. 2001. Introduction of Food Engineering. Academic Press. London, UK. 